\title{
Range of Phytoplasma Concentrations in Various Plant Hosts as Determined by Competitive Polymerase Chain Reaction
}

\author{
R. Berges, M. Rott, and E. Seemüller
}

Biologische Bundesanstalt für Land- und Forstwirtschaft, Institut für Pflanzenschutz im Obstbau, D-6921 Dossenheim, Germany. Accepted for publication 2 June 2000.

\section{ABSTRACT}

Berges, R., Rott, M., and Seemüller, E. 2000. Range of phytoplasma concentrations in various plant hosts as determined by competitive polymerase chain reaction. Phytopathology 90:1145-1152.

For competitive polymerase chain reaction (PCR), an internal standard DNA template was developed that consisted of a highly conserved, internally deleted 16S rDNA fragment of an aster yellows phytoplasma. The internal standard was calibrated using a quantified culture of Acholeplasma laidlawii. Serial dilutions of the internal standard and fixed amounts of target templates from infected plants were coamplified with the same primers, and the products obtained were quantified using an enzyme-linked immunosorbent assay procedure. Analysis of the data revealed that the phytoplasma concentration in the plants examined differed by a factor of about $4 \times 10^{6}$. Phytoplasma concentrations of $2.2 \times 10^{8}$ to
$1.5 \times 10^{9}$ cells per $\mathrm{g}$ of tissue were identified in periwinkles infected with various phytoplasmas. High to moderate concentrations were detected in Malus domestica (apple) genotypes infected with the apple proliferation phytoplasma, Alnus glutinosa (alder) genotypes infected with the alder yellows phytoplasma, and most aster yellows-infected Populus (poplar) genotypes examined. Very low phytoplasma concentrations, ranging from 370 to 34,000 cells per $\mathrm{g}$ of tissue, were identified in proliferationdiseased apple trees on resistant rootstocks 4551 and 4608, yellowsdiseased Quercus robur (oak) trees, and Carpinus betulus (hornbeam) trees. Such low concentrations, which corresponded to about 4 to 340 cells in the reaction mixture, could only be detected and quantified by nested PCR.

Additional keyword: tobacco.
Phytoplasmas are nonculturable prokaryotes of the class Mollicutes (trivial name mycoplasmas) that cause diseases of several hundred plant species $(29,42)$. There is evidence that phytoplasma concentration can vary greatly in infected plants. Low numbers are often observed in woody hosts. For example, electron microscopical examinations show that American elms (Ulmus americana) infected with the elm yellows agent have a very low phytoplasma titer (7) and that flavescence dorée-infected grapevines have a phytoplasma concentration that is often below the detection level of microscopical methods (10). Using 4'-6-diamidino-2-phenylindole (DAPI) fluorescence microscopy, a wide range of phytoplasma concentrations, ranging from not detectable to fairly high numbers, were identified in Malus (apple) genotypes that were experimentally inoculated with the apple proliferation (AP) phytoplasma (20). In poplars infected with the aster yellows (AY) agents, phytoplasmas were detectable by DAPI fluorescence microscopy in Populus alba, rarely in $P$. tremula, and not in $P$. nigra cv. Italica. However, lower phytoplasma concentrations were detected by polymerase chain reaction (PCR) using the nested version (5). There are also examples from eucalyptus and hazel in which phytoplasma numbers were too low to be detected by one-round PCR and in which nested PCR yielded positive results $(27,28)$. High phytoplasma concentrations are usually observed in periwinkle (Catharanthus roseus). However, no firm data is available on the concentration range of phytoplasmas in plant tissue, although phytoplasma concentrations may be an important factor in pathogenicity.

The method of choice to quantify nonculturable disease agents is competitive PCR. With this method, the target DNA is coamplified with internal standard (IS) DNA, which competes for primers.

Corresponding author: E. Seemüller;

E-mail address: erich.seemueller@urz.uni-heidelberg.de

Publication no. P-2000-0802-01R

(C) 2000 The American Phytopathological Society
Quantification is achieved by comparing the relative yield of the PCR products amplified from the target and IS. The relative amounts of each remain constant during the amplification process $(3,13)$. As the IS must be distinguishable from the wild-type target, the competitor is either characterized by the presence or absence of a unique restriction site or differs from the target in length because of either an insertion or deletion of the intervening sequence. Competitive PCR has many applications including quantifying mRNA $(3,13)$ and infecting viruses $(32)$, phytopathogenic, walled bacteria (18), and fungi (30). For quantitation of extremely low amounts of target templates, competitive nested PCR is also being used $(15,16)$.

Phytoplasma quantification by competitive PCR is uncommon. Pressacco and Firrao (34) estimated the amount of phytoplasma DNA in infected periwinkles, and Liu et al. (23) determined the concentrations of an AY phytoplasma in the aster leafhopper (Macrosteles fascifrons). In both of these studies, the relative amounts of target DNA were estimated by comparison with a cloned bacterial DNA fragment as the competitor. The objective of our work was to quantify phytoplasma numbers in various plants hosts for which considerable differences in phytoplasma concentration could be expected. Quantification was performed by comparing the PCR products obtained from the target template with that of the competitor, which was calibrated using a Acholeplasma laidlawii liquid culture.

\section{MATERIALS AND METHODS}

Sources of phytoplasmas and DNA extraction. The phytoplasmas examined included strains maintained in the greenhouse and field-collected samples. Greenhouse-kept phytoplasmas were maintained in periwinkle and included strains COL, SAY, and AV2192 of the AY phytoplasma group and strain AT of the AP phytoplasma. All strains were sampled 4 months after graft inoculation from fully symptomatic plants. Strain AT was also main- 
tained in Nicotiana tabacum (tobacco) cv. Samsun and was sampled at different times after inoculation. Field samples were collected from the following: (i) five 18-year-old 'Golden Delicious' apple trees on rootstocks M 11 (Malus domestica), 4608 (M. sieboldii $\times$ M. purpurea), and 4551 (M. sieboldii $\times$ M. domestica) graft-inoculated with the AP phytoplasma 15 years prior to sampling or naturally infected and grown on the same plot; (ii) four 3-year-old black alder (Alnus glutinosa) trees graft-inoculated with the AY agent 2 years prior to sampling; (iii) two 80-year-old oak (Quercus robur) trees naturally infected with AP-group phytoplasmas (the Munich area of Germany); (iv) one 20-year-old hornbeam (Carpinus betulus) tree naturally infected with an AP-group phytoplasma (southwestern Germany); (v) one 20-year-old tree each of $P$. tremula (aspen) and $P$. nigra cv. Italica (Lombardy poplar) naturally infected with AY-type phytoplasmas (southwestern Germany); (vi) two 10-yearold $P$. alba trees naturally infected with AY-type phytoplasmas (France); and (vii) two 4-year-old P. nigra cv. Italica trees and one 4-year-old $P$. tremula tree, all graft-inoculated with AY-type phytoplasmas 2 years prior to sampling. Berges et al. (5) provide more information on the poplar phytoplasmas and Seemüller et al. (42) provide more information on the taxonomic positions of the phytoplasmas used. As healthy controls, one apple tree and one periwinkle plant, both kept under insect-proof conditions, were included in the study.

Samples were collected from several parts of each plant. From periwinkle and tobacco, DNA was isolated from leaf midribs. From apple trees, either root phloem or leaf midribs were taken. From other trees, both stem phloem and midribs were sampled and mixed prior to extraction. Phloem was prepared as previously described (2). DNA was isolated from $1.0 \mathrm{~g}$ of plant tissue using a phytoplasma-enrichment procedure (1). Ethanol-precipitated DNA from each sample was dissolved in $100 \mu \mathrm{l}$ of water.

Generation of IS. Conserved rDNA of strain SAY was amplified by PCR using primers P1/P7, which anneal to the $5^{\prime}$ end of the $16 \mathrm{~S}$ rRNA gene and the $5^{\prime}$ region of the $23 \mathrm{~S}$ rRNA gene (Fig. 1), respectively, and amplify a 1,800-base pair (bp) DNA fragment (40). The amplification product was purified by phenol-chloroform extraction, and the DNA was digested with restriction endonuclease KpnI (MBI Fermentas, Vilnius, Lithuania). The digestion products were resolved by agarose gel electrophoresis, which revealed the presence of the expected three fragments of 425,475 , and $900 \mathrm{bp}\left(5^{\prime} \rightarrow 3^{\prime}\right)$ (Fig. 1). The two distal fragments were excised from the gel, extracted using the JETsorb kit (GenoMed, Bad Oeynhausen, Germany), and ligated with T4 DNA ligase (Stratagene, La Jolla, CA) according to the protocol of the supplier. For cloning, the ligated distal fragments were reamplified using primer pair P1/tRNA (44), yielding a DNA fragment of about 1,200 bp (Fig. 1).

Cloning was carried out using standard procedures (38). The internally deleted fragment was ligated into the EcoRV restriction site of plasmid vector pBluescript II SK (Stratagene). Ligation efficiency was increased by preincubating the digested vector with Taq polymerase, polymerase buffer, and $2 \mathrm{mM}$ dTTP to create $3^{\prime}$ thymidine overhangs that are complementary to the $3^{\prime}$ adenine overhangs generated by the polymerase during PCR amplification (26). After incubation, the ligation mixture was used to transform competent cells of Escherichia coli strain XL-1 Blue MRF' (Stratagene). Recombinant plasmids were prepared as described by

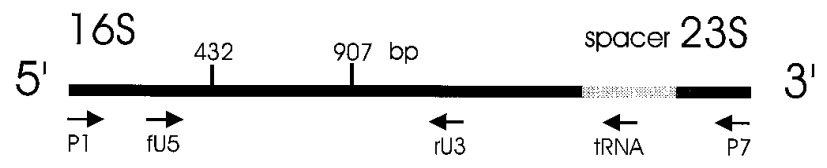

Fig. 1. KpnI restriction map of the rDNA fragment polymerase chain reaction amplified with primer pair P1/P7. Positions of the primers used in the work are also shown.
Sambrook et al. (38). The insert was excised with $P v u I I$ and its identity examined by KpnI digestion (39). One of the clones (AY1) containing the desired 1,200-bp insert was purified and quantified by spectrophotometry for use as an IS template in competitive PCR.

Calibration of IS. The close phytoplasma relative A. laidlawii (strain PG-8) was chosen according to the approach described by $\mathrm{Hu}$ et al. (18) to quantify the walled bacterium Clavibacter michiganensis subsp. sepedonicus in plant tissue. A. laidlawii was grown at $32^{\circ} \mathrm{C}$ for 3 days in liquid $\mathrm{M}$ medium (12). Ten-fold serial dilutions with five replicates of each dilution were made in $\mathrm{M}$ medium, and $200 \mu \mathrm{l}$ of each dilution was plated on standard petri dishes containing agar-solidified $\mathrm{M}$ medium. After 3 days of incubation at $32^{\circ} \mathrm{C}$, colonies were counted under the microscope. Immediately after plating, the cells from each dilution were harvested by centrifugation and genomic DNA extracted according to Doyle and Doyle (11). DNA from $1 \mu \mathrm{l}$ of the dilutions was dissolved in $100 \mu \mathrm{l}$ of Tris-EDTA and quantified by coelectrophoresis with dilutions of defined amounts of calf thymus DNA and with the DNA preparation after it was treated with RNase and precipitated with ethanol by spectrophotometry. The relationship between numbers of colony-forming units (CFU) and the amount of DNA obtained in the two approaches was determined by dividing the DNA quantities by the colony counts. Cell numbers were estimated by considering that the mass of genomic DNA of a single cell of A. laidlawii, whose chromosome size is about 1,580 kilobases (17), is approximately $1.6 \mathrm{fg}$.

To calibrate the PCR product to CFU from the A. laidlawii culture, competitive PCR was performed with $1 \mu \mathrm{l}$ of a $10^{-5}$ dilution of recombinant plasmid AY1 (containing $40 \mathrm{pg}$ of DNA) of internally deleted IS and $1 \mu \mathrm{l}$ of template DNA extracted from 10 -fold serial dilutions of the A. laidlawii culture. For amplification of the 405-bp, internally deleted IS, primer pair fU5/rU3 (5'-CGG CAA TGG AGG AAA CT-3'/5'-TTC AGC TAC TCT TTG TAA CA-3') (24) was used (Fig. 1). The corresponding fragment of A. laidlawii, which was about $880 \mathrm{bp}$, was amplified with primers $\mathrm{fU} 5 \mathrm{Al} / \mathrm{rU} 3 \mathrm{Al}$ (5'-CGG CAA TGG GGG AAA CC-3'/5'-TAT CGC TTC TCT TTG TTC CA-3'), which differ from fU5/rU3 in two and six positions, respectively. Amplification was conducted as described (24), except that the amounts of polymerase, polymerase buffer, and dNTPs were duplicated. PCR was repeated four times for estimation of an average value. In preliminary work and for rapid examination, the PCR products were compared and quantified by electrophoresis in an ethidium bromide-stained agarose gel. The competition equivalence point was determined when both products showed similar fluorescence intensity, considering that fluorescence is affected by the different sizes of the two fragments ( 880 versus $405 \mathrm{bp}$ ).

For more precise quantification, an enzyme-linked immunosorbent assay (ELISA) procedure based on protocols described by Lüneberg et al. (25) and Berg et al. (4) was used. As described above, the IS template and dilutions of the A. laidlawii DNA template were amplified with primer pairs fU5/rU3 and fU5Al/rU3Al, respectively. Primers fU5 and fU5Al were labeled with biotin to mediate immobilization of the amplification products on streptavidin-coated microtiter plates (Labsystems, Helsinki, Finland). After denaturation by alkali treatment, digoxigenin-labeled oligonucleotide probes U1comp (5'-TTT GCT CCC CAC GCT TTC GT-3') and U2comp (5'-CTG ATA ACC TCC ACT AT-3') were hybridized to the single-stranded immobilized PCR fragments. Since the target sequence of probe U1comp was deleted in the IS, it could hybridize only to the PCR product obtained from the A. laidlawii template. In contrast, due to six mismatches with the A. laidlawii sequence, probe U2comp hybridized only to the IS. Therefore, two sets of samples were prepared in triplicate, one of which was hybridized with probe U1comp and the other with probe U2comp. Hybrids were detected by ELISA using an alkaline phosphataseconjugated antibody (Roche Diagnostics, Mannheim, Germany) and 4-nitrophenyl phosphate as substrate (Roche Diagnostics). Optical density was measured with a Titertek Multiscan MCC/340 
ELISA reader (Flow Laboratories, Bioggio, Switzerland) at $405 \mathrm{~nm}$. The cut-off value was determined by adding three standard deviations to the mean of the negative control.

Values obtained by competitive amplification of the $10^{-5}$ dilution of the IS template and the serially diluted A. laidlawii template were related by determining the competition equivalent point at which the ELISA readings from the IS and the A. laidlawii competitor are equal. This was done by plotting the $\log _{10}$ of the PCR product ratio (amount of IS product/A. laidlawii product) for each DNA concentration against the $\log _{10}$ of the values obtained from the DNA dilutions of the A. laidlawii competitor as a function of the $\log _{10}$ of the number of copies of competing template added (31). Graphically, this transformation yielded a linear plot (Fig. 2C). Interpolation on the plot for a Y value of $0\left(\log _{10} 1=0\right)$ gives the number of copies corresponding to the equivalence point and, hence, to $\mathrm{CFU}$ from the A. laidlawii culture.

Phytoplasma concentrations in plants. To determine phytoplasma concentrations in infected plant tissue, $1 \mu \mathrm{l}$ of sample DNA and a 10-fold serial dilution of the calibrated IS DNA template were amplified by competitive PCR using primer pair fU5/rU3, which amplifies a fragment of about $880 \mathrm{bp}$ from the target template. Primer fU5 was biotin-labeled when the PCR products were quantified by ELISA. For phytoplasma detection in trees, in which the phytoplasma concentrations were too low to be detected by oneround PCR, nested PCR with primer pair P1/tRNA in the first round and primer pair fU5/rU3 in the second round were employed. For nested amplification, in which the PCR parameters were the same as in the first round, 1:100 dilutions of the products of the first round were used as a template. As described above, two sets of samples were prepared. One of them was hybridized with probe U1comp and the other with probe U2comp. As probe U2comb hybridized to both the IS and target, the readings obtained with probe U1comb were subtracted from the U2comp readings in order to determine the values for the competitor alone. The competition equivalence point was determined as described above for the IS and A. laidlawii templates, using the IS as the competitor and sample DNA as the target template. Identities of plant-associated phytoplasmas were determined by restriction fragment length polymorphism (RFLP) analysis of the PCR-amplified DNA using $A l u \mathrm{I}$ and $R s a \mathrm{I}$ restriction endonucleases that allow classification of major phylogenetic groups (39).

Detection thresholds of PCR procedures. To determine the detection thresholds of the procedures used, samples from four different plant species were selected for which the phytoplasma concentrations were previously determined by competitive PCR. From these samples, 10-fold serial dilutions were made that were amplified by direct or nested PCR. Amplification products were detected by agarose gel electrophoresis or ELISA as described above.

\section{RESULTS}

Calibration of IS. Colony counts from 10-fold serial dilutions of a 3-day-old liquid culture of A. laidlawii resulted in an average value of $1.17 \times 10^{9} \mathrm{CFU} / \mathrm{ml}$. At this titer, a mean DNA concentration of $150 \mu \mathrm{g} / \mathrm{ml}$ was determined by both comparative electrophoresis and spectrophotometry, resulting in a calculated mass of $128 \mathrm{fg}$ of DNA per CFU. Considering a DNA mass of $1.6 \mathrm{fg}$ for a single A. laidlawii chromosome, a CFU/cell ratio of 1:80 was calculated. This value is about in the middle of the range found in previous work in which $1 \mathrm{CFU}$ was shown to be equivalent to 10 to 1,000 mycoplasma cells (36). From the CFU/ml value of the $A$. laidlawii culture and the $\mathrm{CFU} /$ cell ratio, an acholeplasma concentration of $9.4 \times 10^{10}$ cells per ml was calculated.

To calibrate the IS, competitive amplification of a $10^{-5}$ dilution of the IS template together with a 10 -fold serial dilution of the $A$. laidlawii competitor was performed. With decreasing amounts of A. laidlawii DNA, the amount of the 880-bp PCR product from $A$. laidlawii decreased, whereas the amount of the 405-bp product from the IS increased (Fig. 2A and B). Plotting $\log _{10}$ ratios of the values for the IS and A. laidlawii DNA dilutions against $\log _{10}$ values obtained from the $A$. laidlawii dilutions resulted in a linear regression line (Fig. 2C). Interpolation of the plot for a $\mathrm{Y}$ value of 0 gave an equivalence point at $\log _{10}$ of 2.68 , which corresponded to a dilution of $4.79 \times 10^{2}$ for the $A$. laidlawii culture. This dilution corresponded to a concentration of $1.95 \times 10^{8}$ cells per $\mathrm{ml}$ of

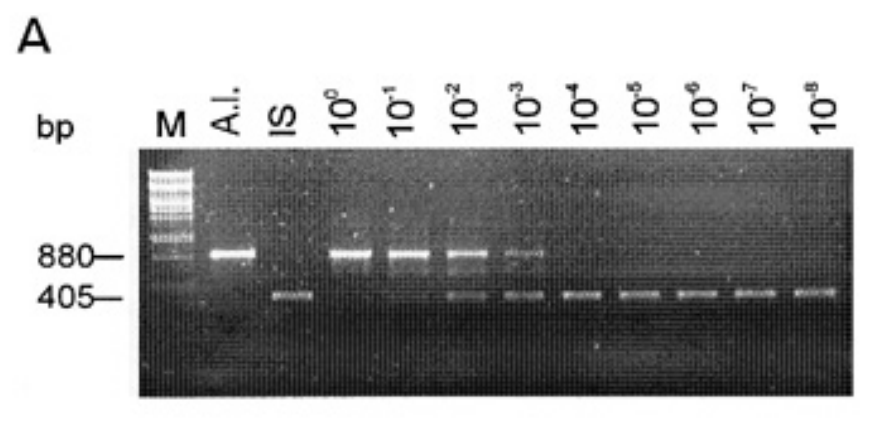

B
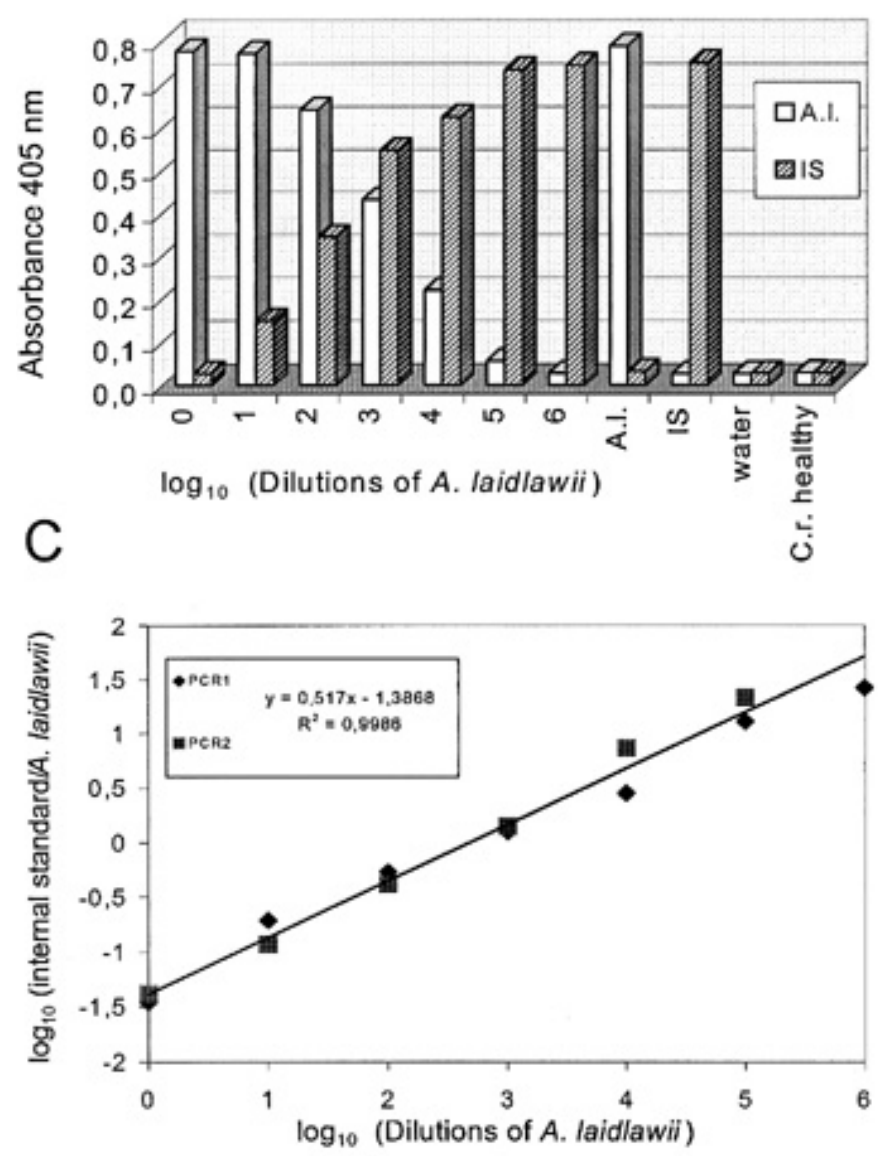

Fig. 2. Calibration of the internal standard (IS) by competitive polymerase chain reaction (PCR) amplification of $40 \mathrm{pg}$ of the IS template and a 10-fold serial dilution of the Acholeplasma laidlawii culture. A, Electrophoretically resolved, ethidium bromide-stained PCR products from the IS template (lower band) and decreasing amounts of the competitive A. laidlawii template (upper band). Additional bands are due to heteroduplex formation. $\mathrm{M}=$ size marker, A.1. = product from the undiluted A. laidlawii template, and IS = product from the IS alone. At a $10^{-2}$ to $10^{-3}$ dilution of the competitor, the amount of products is similar. B, Quantitation of the amplification products shown in $\mathbf{A}$ by enzyme-linked immunosorbent assay (ELISA). C.r. healthy = template from healthy periwinkle. C, Determination of equivalence point $\left(\log _{10}\right.$ of ratio IS/competitor $\left.=0\right)$ by plotting the ELISA data shown in $\mathbf{B}$. At a $10^{-2.68}$ dilution of the competitor, the amounts of products from the IS template and the calibrated A. laidlawii template are identical. 
the A. laidlawii culture. This value differs from the concentration of the IS. Forty picograms of IS DNA, which is contained in the $10^{-5}$ dilution, corresponded to nearly $10^{7}$ copies of the recombinant plasmid. Since phytoplasmas and A. laidlawii both possess two rRNA operons, this number corresponds to about $5 \times 10^{6} \mathrm{~mol}-$ licute cells, which is equivalent to about $5 \times 10^{8}$ cells per ml. This value is about 2.4 times greater than the corresponding cell number of the A. laidlawii culture.

Phytoplasma concentrations in plants. For quantitation of phytoplasma concentrations in infected plants, the IS value based
A
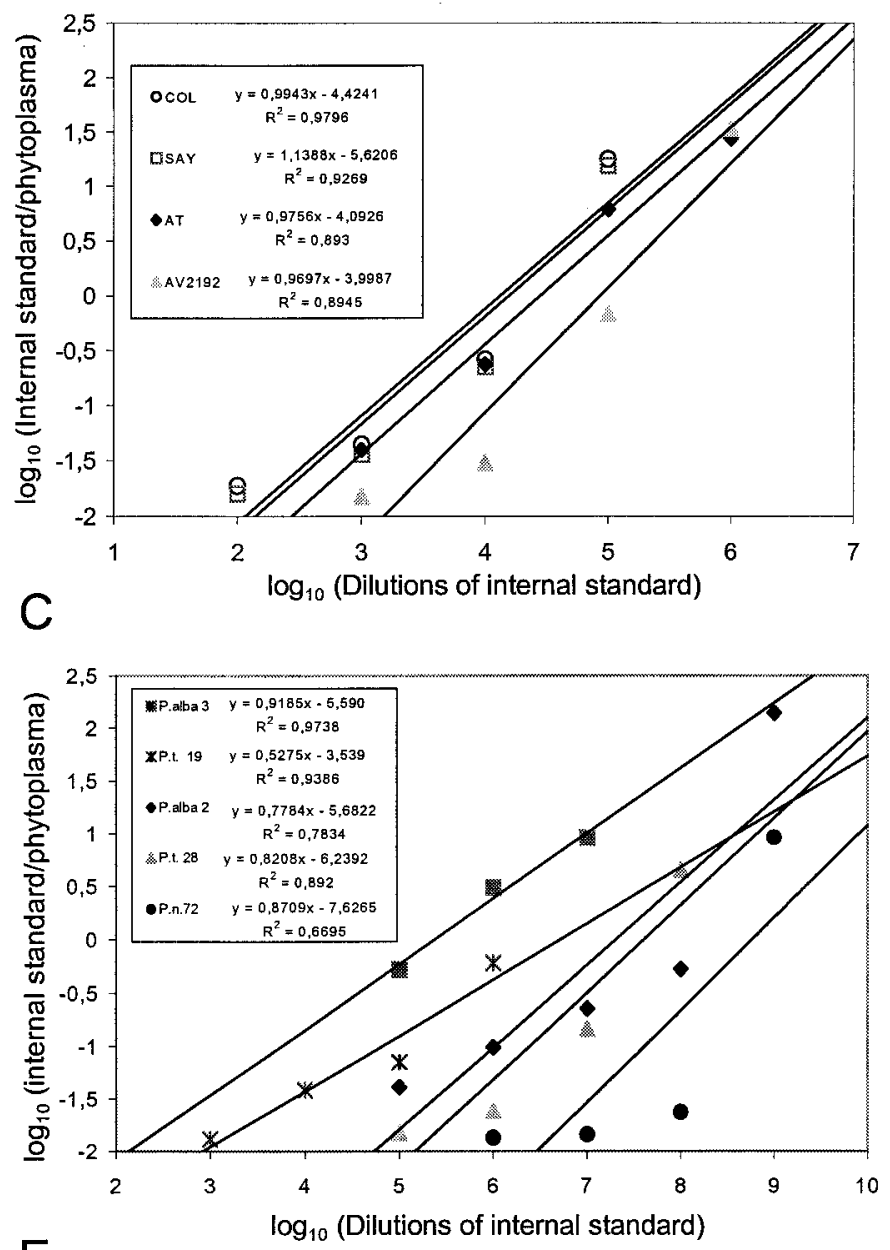

$E$

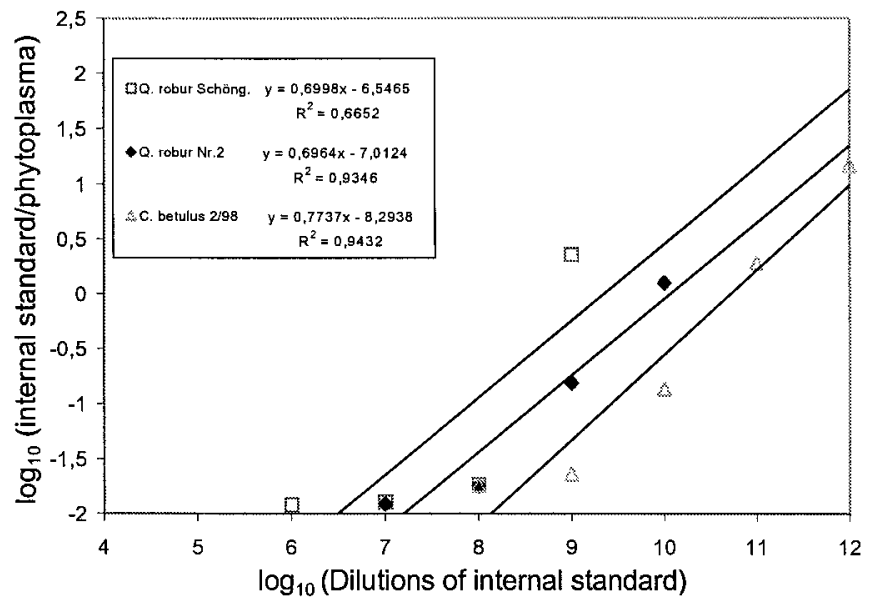

B
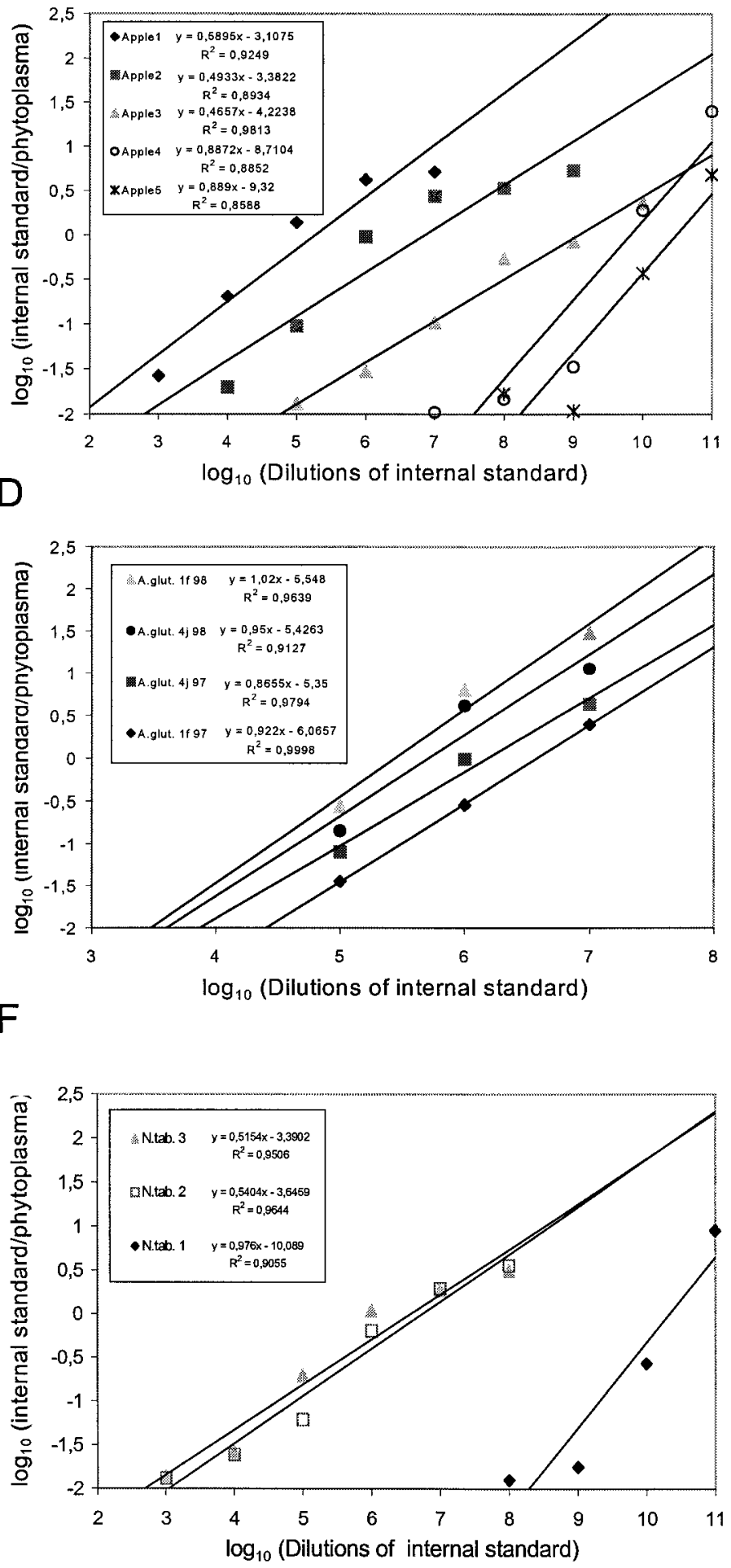

Fig. 3. Quantitation of phytoplasma concentrations in various diseased plants by plotting the ratios of polymerase chain reaction products from the internal standard/phytoplasma template against the products from 10-fold serial dilutions of the internal standard as the competitor. A, Periwinkle-maintained strains COL, SAY, AT, and AV2192; B, samples from apple proliferation-infected 'Golden Delicious' apple trees on various rootstocks; C, samples from infected poplars (Populus alba 3 is not shown); D, samples from alder yellows-infected alder trees; E, samples from oak and hornbeam; F, samples from strain AT-infected tobacco, collected 3 (1), 6 (2), and 10 (3) weeks postinoculation. Table 1 provides equivalence points, phytoplasma concentrations, and more information about samples. The order of the regression lines (from left to right) corresponds to the order of the data listed in the boxed area (from top to bottom). 
its calibration on A. laidlawii culture. It was carried out by competitive amplification of $1 \mu \mathrm{l}$ of target template with a 10 -fold serial dilution of the IS competitor. ELISA readings with the DNA template from healthy plants and other controls were usually below 0.034 . The cut-off value for positive samples was defined as 0.066 . Correlation coefficients of the regression lines $\left(R^{2}\right)$ obtained by plotting the ratios of the values obtained from the target template and IS dilutions against the IS dilutions were mostly near 0.9 or above, indicating a high level of accuracy (Fig. 3).

In periwinkle infected with strains AT, SAY, AV2192, and COL, phytoplasma numbers differed significantly. When $\log _{10}$ ratios of values obtained from the target template and IS dilutions were plotted against the $\log _{10}$ of the IS dilutions, $\log _{10}$ equivalence points between 4.12 and 4.94 were determined (Fig. 3A). These values correspond to between $1.5 \times 10^{9}$ and $2.2 \times 10^{8}$ phytoplasma cells per $1.0 \mathrm{~g}$ of infected periwinkle tissue, considering that a $10^{-5} \mathrm{di}$ lution of the IS corresponds to $1.95 \times 10^{8} \mathrm{~A}$. laidlawii cells per $\mathrm{ml}$ and that the total volume of DNA extract per gram of tissue was $100 \mu \mathrm{l}$ (Table 1).

Examination of samples from infected trees yielded an extremely wide range of phytoplasma concentrations. The phytoplasma concentration in the root phloem of an AP-diseased 'Golden Delicious' apple tree on rootstock M 11 was $1.0 \times 10^{8}$ cells per $g$ of tissue, a value near that of periwinkle infected with strain AV2192. In the 'Golden Delicious' scion cultivar of a second apple tree on rootstock M 11, which showed witches' broom symptoms like the above tree but from which leaf midribs were examined, the phytoplasma concentration was markedly lower. Low to extremely low phytoplasma numbers, ranging from $1.7 \times 10^{4}$ to $6.5 \times 10^{2}$ cells per $g$ of tissue, were detected in leaf midribs from three diseased trees of the same cultivar grown on experimental rootstocks 4551 and 4608 (Table 1; Fig. 3B). These trees showed no or only mild yellowing symptoms.

A wide range of phytoplasma concentrations were also identified in Populus spp. infected with AY-type phytoplasmas showing yellowing and decline symptoms (Table 1; Fig. 3C). Values ranged from $8.3 \times 10^{7}$ to $3.4 \times 10^{4}$ cells per $\mathrm{g}$ of tissue for $P$. nigra $\mathrm{cv}$. Italica, whereas numbers detected in $P$. alba and $P$. tremula were between these concentrations. In Alnus glutinosa trees experimentally inoculated with the alder yellows phytoplasma and exhibiting mild yellowing symptoms, phytoplasma concentrations were relatively uniform and in the upper range of values found for trees (Table 1; Fig. 3D). Very low concentrations were identified in yellowish and declining trees of $Q$. robur (oak) and Carpinus betulus (hornbeam) (Table 1; Fig. 3E). Both oak and hornbeam were infected with AP-group phytoplasmas as determined by RFLP analysis of the PCR products obtained with primer pair fU5/rU3 (data not shown). A more detailed differentiation of the infecting agents was not possible based on the method used.

Development of phytoplasmal infection in tobacco. Three weeks after graft inoculation with the AP agent, phytoplasma concentrations in tobacco were very low, just reaching $8.9 \times 10^{2}$ cells per $g$ of tissue. After this point, phytoplasma numbers increased rapidly and by the end of the sixth week a titer of $3.5 \times 10^{6}$ cells per $g$ of tissue was determined. Further growth was slow, and at 10 weeks postinoculation (p.i.) the phytoplasma concentration reached $5.1 \times 10^{6}$ cells per g of tissue (Table 1, Fig. 3F). A similar time course has been described for other plants inoculated with AY phytoplasmas (43).

Sensitivity of PCR procedures used. By competitive one-round PCR, the lowest concentration detected was for the AY phytoplasma in $P$. tremula 28 , estimated to be $4.9 \times 10^{3}$ cells in the reaction mixture $\left(4.9 \times 10^{5}\right.$ cells per $\mathrm{g}$ of tissue). For all lower concentrations, starting with AY phytoplasma in $P$. nigra cv. Italica 72 , nested PCR was required for detection. The sample from $P$. nigra $\mathrm{cv}$. Italica 72 was estimated to contain 340 cells in the reaction mixture. The three lowest phytoplasma concentrations detected by nested PCR ranged from about four to nine cells (Table 1).
Tests to determine detection thresholds were done by amplifying 10-fold serial dilutions of target templates from strain AT in periwinkle, strain AT in tobacco (10 weeks p.i.), AP phytoplasma in rootstock M 11, and AY phytoplasma in P. tremula 28 , selected from the samples listed in Table 1 . Results largely confirm the values obtained by competitive PCR (Table 1). The end point for detection of amplification products depended on the method used (Table 2). When products from one-round PCR were visualized by agarose gel electrophoresis, 490 to 1,000 phytoplasma cells could be detected in the reaction mixture, which contained $1 \mu \mathrm{l}$ of sample DNA. Detection sensitivity of ELISA was similar or 10 times better than agarose gel electrophoresis. Nested PCR was 10 times more sensitive than one-round PCR followed by ELISA detection,

TABLE 1. Phytoplasma concentrations in various plant hosts as determined by competitive polymerase chain reaction ${ }^{\mathrm{y}}$

\begin{tabular}{|c|c|c|c|}
\hline Phytoplasma ${ }^{z}$ & Host plant & $\begin{array}{l}\log _{10} \text { of } \\
\text { equivalen } \\
\text { point }\end{array}$ & $\begin{array}{l}\text { Cells/g } \\
\text { tissue }\end{array}$ \\
\hline AY strain $\mathrm{COI}$ & $\begin{array}{l}\text { Catharanthus roseus, } \\
\text { experimentally inoculated }\end{array}$ & 4.12 & $1.5 \times 10^{9}$ \\
\hline AY strain SAY & $\begin{array}{l}\text { C. roseus, } \\
\text { experimentally inoculated }\end{array}$ & 4.20 & $1.2 \times 10^{9}$ \\
\hline AP strain AT & $\begin{array}{l}\text { C. roseus, } \\
\text { experimentally inoculated }\end{array}$ & 4.45 & $6.9 \times 10^{8}$ \\
\hline AY strain AV2192 & $\begin{array}{l}\text { C. roseus, } \\
\text { experimentally inoculated }\end{array}$ & 4.94 & $2.2 \times 10^{8}$ \\
\hline AP phytoplasma & $\begin{array}{l}\text { Apple 1, M } 11 \text { rootstock, } \\
\text { naturally infected }\end{array}$ & 5.27 & $1.0 \times 10^{8}$ \\
\hline AY phytoplasma & $\begin{array}{l}\text { Populus nigra cv. Italica } 12 \text {, } \\
\text { naturally infected }\end{array}$ & 5.37 & $8.3 \times 10^{7}$ \\
\hline ALY phytoplasma & $\begin{array}{l}\text { Alnus glutinosa } 1 \mathrm{f} / 98, \\
\text { experimentally inoculated }\end{array}$ & 5.44 & $7.1 \times 10^{7}$ \\
\hline ALY phytoplasma & $\begin{array}{l}\text { A. glutinosa } 4 \mathrm{j} / 98 \text {, } \\
\text { experimentally inoculated }\end{array}$ & 5.71 & $3.8 \times 10^{7}$ \\
\hline AY phytoplasma & $\begin{array}{l}P . \text { alba } 3 \text {, } \\
\text { naturally infected }\end{array}$ & 6.08 & $1.6 \times 10^{7}$ \\
\hline ALY phytoplasma & $\begin{array}{l}\text { A. glutinosa } 4 \mathrm{j} / 97 \text {, } \\
\text { experimentally inoculated }\end{array}$ & 6.18 & $1.3 \times 10^{7}$ \\
\hline AP strain AT & $\begin{array}{l}\text { Nicotiana tabacum cv. Samsun, } \\
10 \text { weeks postinoculation }\end{array}$ & 6.58 & $5.1 \times 10^{6}$ \\
\hline ALY phytoplasma & $\begin{array}{l}\text { A. glutinosa } 1 \mathrm{f} / 97 \text {, } \\
\text { experimentally inoculated }\end{array}$ & 6.58 & $5.1 \times 10^{6}$ \\
\hline AY phytoplasma & $\begin{array}{l}\text { P. tremula } 19, \\
\text { naturally infected }\end{array}$ & 6.71 & $3.8 \times 10^{6}$ \\
\hline AP strain AT & $\begin{array}{l}\text { N. tabacum cv. Samsun, } \\
6 \text { weeks postinoculation }\end{array}$ & 6.75 & $3.5 \times 10^{6}$ \\
\hline AP phytoplasma & $\begin{array}{l}\text { Apple } 2 \text {, 'Golden Delicious' on } \\
\text { rootstock M 11, naturally infected }\end{array}$ & 6.86 & $2.7 \times 10^{6}$ \\
\hline AY phytoplasma & $\begin{array}{l}P . \text { alba } 2 \text {, } \\
\text { naturally infected }\end{array}$ & 7.29 & $1.0 \times 10^{6}$ \\
\hline AY phytoplasma & $\begin{array}{l}\text { P. tremula } 28, \\
\quad \text { experimentally inoculated }\end{array}$ & 7.60 & $4.9 \times 10^{5}$ \\
\hline AY phytoplasma & $\begin{array}{l}\text { P. nigra } \mathrm{cv} \text {. Italica } 72 \text {, } \\
\text { experimentally inoculated }\end{array}$ & 8.76 & $3.4 \times 10^{4}$ \\
\hline AP phytoplasma & $\begin{array}{l}\text { Apple 3, 'Golden Delicious' on } \\
\text { rootstock 4551, } \\
\text { experimentally inoculated }\end{array}$ & 9.07 & $1.7 \times 10^{4}$ \\
\hline AP-gr & $\begin{array}{l}\text { Quercus robur Schöng., } \\
\text { naturally infected }\end{array}$ & 9.35 & $8.7 \times 10^{3}$ \\
\hline $\mathrm{AP} p$ & $\begin{array}{l}\text { Apple 4, 'Golden Delicious' on } \\
\text { rootstock } 4608 \text {, } \\
\text { experimentally inoculated }\end{array}$ & 9.82 & $3.0 \times 10^{3}$ \\
\hline AP-grc & $\begin{array}{l}Q . \text { robur } \text { No. } 2 \text {, } \\
\text { naturally infected }\end{array}$ & 10.07 & $1.7 \times 10^{3}$ \\
\hline AP phytoplasma & $\begin{array}{l}\text { N. tabacum cv. Samsun, } \\
3 \text { weeks postinoculation }\end{array}$ & 10.34 & $8.9 \times 10^{2}$ \\
\hline AP phytoplasma & $\begin{array}{l}\text { Apple 5, 'Golden Delicious' on } \\
\text { rootstock 4551, } \\
\text { experimentally inoculated }\end{array}$ & 10.48 & $6.5 \times 10^{2}$ \\
\hline plasm & $\begin{array}{l}\text { Carpinus betulus, } \\
\text { naturally infected }\end{array}$ & 10.72 & $3.7 \times 10^{2}$ \\
\hline
\end{tabular}

${ }^{y}$ Nested polymerase chain reaction was required for quantification of the last eight samples listed in the table.

${ }^{\mathrm{z}} \mathrm{AY}=$ aster yellows; $\mathrm{AP}=$ apple proliferation; and $\mathrm{ALY}=$ alder yellows. 
irrespective if the amplification products were detected by ELISA or agarose gel electrophoresis. Nested PCR allowed the detection of 5 to 69 cells in the reaction mixture. An example of comparing direct and nested PCR and detection of the amplification products by agarose gel electrophoresis and ELISA is shown in Figure 4. The detection threshold for target templates from the A. laidlawii culture and the internal control were in the same range as the phytoplasma samples (Table 2).

\section{DISCUSSION}

In this work, a sensitive method is described to quantify phytoplasmas in infected plants by competitive PCR. With this procedure, a fixed amount of sample DNA was coamplified with a dilution series of calibrated IS DNA as the competitor. This competitor consisted of a highly conserved 16S rDNA fragment. Thus, both competitor and sample target could be amplified with primer pair fU5/rU3, which is known to amplify the target sequence from templates of all phytoplasmas $(24,41)$. The IS was characterized by an internal deletion that enabled distinction from the wild-type target. For estimation of phytoplasma numbers in infected tissue, the competitor was calibrated using a A. laidlawii culture of known cell concentration. CFU and cell number values obtained from this culture were in agreement with values reported by Razin $(35,36)$. Since phytoplasmas and A. laidlawii both have two sets of rRNA operons (37), A. laidlawii culture cell numbers could, via IS, be directly related to phytoplasma concentrations in infected plant tissue.

Calculation of phytoplasma concentrations on the basis of the copy number of the competitor resulted in values that were about 2.4 times higher than those based on IS parameters obtained by calibration to the A. laidlawii culture. The difference between these two values is insignificant compared with the variance in phytoplasma numbers observed between infected plants of the same species or between different stages of disease of the same plant. The principle findings, identification of the range of phytoplasma concentrations in various plants, are not altered. The reason for the differences in the calibration of the IS is unclear. It is possible that it was more efficiently amplified than rDNA of $A$. laidlawii.

Amplification of sample DNA with primer pair fU5/rU3 yielded a fragment that was more than twice the size of the IS product. However, as the elongation time was adjusted for amplification of the larger target fragment, there is no indication of a negative effect on the amplification efficiency of the two fragments, as shown in other work with differently sized targets $(13,14,18)$.

TABLE 2. Detection thresholds of one-round and nested polymerase chain reactions (PCR) in phytoplasma detection, depending on the amplicon detection method

\begin{tabular}{|c|c|c|c|}
\hline \multirow[b]{3}{*}{ Template } & \multicolumn{3}{|c|}{$\begin{array}{l}\text { Detection thresholds } \\
\text { (cells in reaction mixture) }\end{array}$} \\
\hline & \multicolumn{2}{|c|}{ One-round PCR } & \multirow{2}{*}{$\frac{\text { Nested PCR }}{\text { Agarose gel/ELISA }}$} \\
\hline & Agarose gel & ELISA $^{x}$ & \\
\hline Strain AT in periwinkle ${ }^{y}$ & 690 & 690 & 69 \\
\hline $\begin{array}{l}\text { AP phytoplasma/ } \\
\text { Rootstock M } 11^{y}\end{array}$ & 1,000 & 100 & 10 \\
\hline $\begin{array}{l}\text { Strain AT/ } \\
\text { Tobacco }(10 \text { weeks p.i. })^{y}\end{array}$ & 510 & 51 & 5 \\
\hline $\begin{array}{l}\text { AY phytoplasma/ } \\
\text { Populus tremula } 28^{\mathrm{y}}\end{array}$ & 490 & 490 & 49 \\
\hline Acholeplasma laidlawii & 940 & n.d. ${ }^{z}$ & 9 \\
\hline Internal standard & 1,950 & n.d. & 20 \\
\hline
\end{tabular}

${ }^{\mathrm{w}} \mathrm{AP}=$ apple proliferation and $\mathrm{AY}=$ aster yellows.

${ }^{\mathrm{x}}$ ELISA = enzyme-linked immunosorbent assay.

${ }^{\mathrm{y}}$ Table 1 provides phytoplasma concentrations in an undiluted sample. p.i. $=$ postinoculation.

${ }^{z}$ Not done.
Also, the differences in fragment size did not affect the quantification of the PCR products, because they were measured by ELISA following a hybridization procedure that was not affected by fragment length. In contrast, quantitation of the products by electrophoresis in an ethidium bromide-stained gel depends on fragment size because of the intercalating dye and was thus only used for quick comparisons and preliminary estimations.

Previous work by electron and fluorescence microscopy, serology, nucleic acid hybridization, and standard PCR indicated that there must be a wide range of phytoplasma numbers in infected plant tissue. Our work showed that phytoplasma concentrations in the plants examined differed by a factor of $4.0 \times 10^{6}$. The differing phytoplasma concentrations determined in this work by quantitative PCR agree with previous observations based on other methods. Highest concentrations were detected in periwinkles infected with various phytoplasmas. This plant is generally considered to be a high-titer host and is, for this reason, preferentially used as phytoplasma source for molecular and other studies. Relatively high to moderately high concentrations were also identified in apple trees on $M$. domestica rootstocks, in alder, and in most poplars examined. These findings also confirm observations from previous work $(5,20,21)$. While phytoplasma concentrations in the above plants could be quantified using oneround PCR, nested PCR was required for phytoplasma quantification in apple trees on the apomictic rootstock selections 4608 and 4551, oak, hornbeam, and one $P$. nigra cv. Italica tree. These results also agree with previous work that showed that in some Populus genotypes phytoplasmas can be detected only by nested PCR (5) and that very low phytoplasma concentrations occur in apple rootstock $4551(19,20)$, which may affect phytoplasma concentrations in the scion. There is also a report of very low phytoplasma numbers in oak (2). Although only one sample per
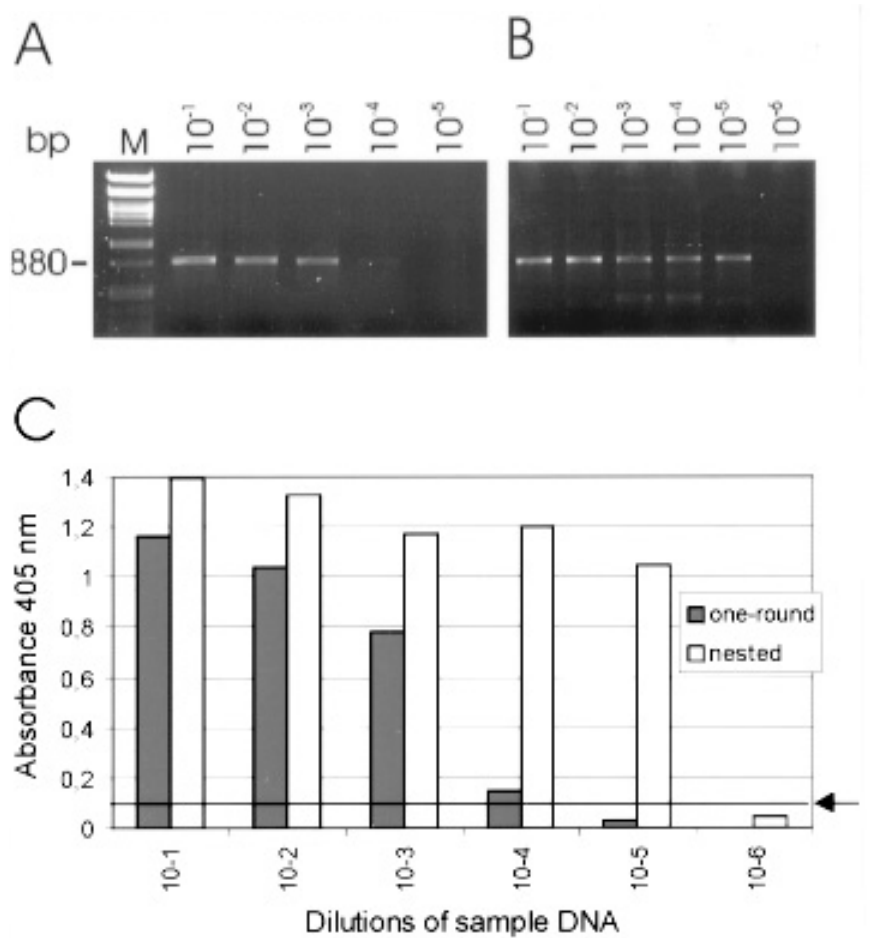

Fig. 4. Detection thresholds of apple proliferation phytoplasmas (strain AT) in infected periwinkle by one-round and nested polymerase chain reactions (PCR). Amplification products from 10-fold serial dilutions of the target template were detected by either electrophoresis in an ethidium bromide-stained agarose gel (A, one-round PCR; $\mathbf{B}$, nested PCR) or $\mathbf{C}$, enzyme-linked immunosorbent assay. The starting concentration of the target template is shown in Table 1, and the threshold levels are shown in Table $2 . \mathrm{M}=$ size marker. Arrow indicates the cut-off value for samples rated as positive as described in text. 
plant was examined, the fact that our data confirmed the expected differences in phytoplasma concentrations between various host plants indicates that the values obtained are not due to variability among samples. This conclusion is also supported by the finding that some groups of plants such as periwinkle, alder, and oak showed the same range on concentrations. In other cases, such as apple and tobacco, the differences can be explained by rootstock and time of inoculation, respectively.

In our work, nested PCR increased sensitivity considerably. Whereas the detection threshold of one-round PCR was approximately 500 cells, nested PCR extended the range of detection and quantification to about five cells. A progressive extension of the results obtained with nested PCR over one-round PCR gives an indication of the reliability of this method. The accuracy of our phytoplasma quantification study is also evidenced by the fact that the detection thresholds of both standard and nested PCR were largely similar, whether determined by competitive PCR or by PCR amplification of a dilution series of the calibrated target templates. Nested PCR was usually 10 to 100 times more sensitive than oneround PCR followed by agarose gel electrophoresis of the amplification products. ELISA detection increased sensitivity of oneround PCR but not of nested PCR. A higher sensitivity of PCRELISA than of electrophoretical detection of the amplification products following one-round PCR was also reported by Poggi Pollini et al. (33).

Pressacco and Firrao (34) estimated that the detection threshold of competitive one-round PCR is 0.3 to $3.0 \mathrm{ng}$ of target DNA. Considering a chromosome size of about $1 \mathrm{Mb}$, these amounts correspond to 300 to 3000 phytoplasma cells, a range similar to that identified in our work. However, Liu et al. (23) were able to quantify with a similar method 1 to $10^{7}$ copies of phytoplasma templates extracted from the leafhopper Macrosteles fascifrons. Also, 1 to 250 genomes of human-pathogenic mycoplasmas could be detected by one-round PCR $(4,9,45)$. These results may indicate that amplification of phytoplasmal DNA extracted from plants is less efficient than that of mycoplasmal DNA extracted from in vitro cultures or insect and mammalian tissues, perhaps because of the presence of endogenous inhibitory substances in plant or other tissues. However, by the use of nested PCR, the sensitivity for samples derived from plants was similar to that extracted from pure cultures or animal tissues.

Although phytoplasma-host interactions are poorly understood, there is an indication that phytoplasma numbers in infected plant tissue may be an important pathological factor. It is possible that different mechanisms of pathogenicity exist in high-titer hosts and low-titer hosts. It is also conceivable that plants differing in host suitability, and thus phytoplasma titer, may respond differently to infection. For example, AP phytoplasma-infected trees on $M$. domestica and $M$. silvestris roots show relatively high pathogen titers and form witches'-brooms as a specific symptom, but sieve tubes are little affected and the trees usually do not decline. In contrast, in genotypes of $M$. tschonoskii, M. sargentii, and $M$. kansuensis, phytoplasma titers are extremely low and only nonspecific yellowing symptoms develop. Also, severe sieve tube necrosis is observed, and grafted trees often decline (19,20). A similar situation exists in elm yellows-infected species of the genus Ulmus. $U$. americana and $U$. rubra are low-titer hosts that develop nonspecific symptoms and decline, whereas $U$. minor $(=U$. carpinifolia) and $U$. laevis are relatively high-titer hosts that form specific witches'-broom symptoms and are less prone to decline $(7,8)$. Another question is whether extremely low phytoplasma populations as quantified in this work by competitive nested PCR in oak and hornbeam trees showing nonspecific yellowing symptoms are disease causing or just contamination. There are reports on the detection of low phytoplasma numbers in European hackberry and fruit trees showing nonspecific, mild, or no symptoms in which the pathological significance of the colonizing mollicutes appears to be unclear $(6,22)$.

\section{ACKNOWLEDGMENTS}

We thank R. Herrmann for providing Acholeplasma laidlawii strain PG-8 and U. Ahrens for providing the sequences of probes U1comp and U2comp. Phytoplasma strain SAY was provided by B. C. Kirkpatrick.

\section{LITERATURE CITED}

1. Ahrens, U., and Seemüller, E. 1992. Detection of DNA of plant pathogenic mycoplasmalike organisms by a polymerase chain reaction that amplifies a sequence of the $16 \mathrm{~S}$ rRNA gene. Phytopathology 82 : 828-832.

2. Ahrens, U., and Seemüller, E. 1994. Detection of mycoplasmalike organisms in declining oaks by polymerase chain reaction. Eur. J. For. Pathol. 24:55-63.

3. Becker-André, M., and Hahlbrock, K. 1989. Absolute mRNA quantification using the polymerase chain reaction (PCR). A novel approach by a PCR aided transcript titration assay (PATTY). Nucleic Acids Res. 17: 9437-9446.

4. Berg, S., Lüneberg, E., and Frosch, M. 1996. Development of an amplification and hybridization assay for the specific and sensitive detection of Mycoplasma fermentans DNA. Mol. Cell. Probes 10:7-14.

5. Berges, R., Cousin, M. T., Roux, J., Mäurer, R., and Seemüller, E. 1997. Detection of phytoplasma infections in declining Populus nigra 'Italica' trees and molecular differentiation of the aster yellows phytoplasmas identified in various Populus species. Eur. J. For. Pathol. 27:33-43.

6. Bertaccini, A., Mittempergher, L., and Vibio, M. 1996. Identification of phytoplasmas associated with a decline of European hackberry (Celtis australis). Ann. Appl. Biol. 128:245-253.

7. Braun, E. J., and Sinclair, W. A. 1976. Histopathology of phloem necrosis in Ulmus americana. Phytopathology 66:598-607.

8. Braun, E. J., and Sinclair, W. A. 1979. Phloem necrosis of elms: Symptoms and histopathological observations in tolerant hosts. Phytopathology 69:354-358.

9. Buck, G. E., O’Hara, L. C., and Summersgill, J. T. 1992. Rapid, sensitive detection of Mycoplasma pneumoniae in simulated clinical specimens by DNA amplification. J. Clin. Microbiol. 30:3280-3283.

10. Caudwell, A., and Kuszala, K. 1992. Mise au point d'un test ELISA sur les tissus de vignes atteintes de flavescence dorée. Res. Microbiol. 143: 791-806.

11. Doyle, J. J., and Doyle, J. L. 1990. Isolation of plant DNA from fresh tissue. Focus (BRL) 12:13-15.

12. Eden-Green, S. J., and Tully, J. G. 1979. Isolation of Acholeplasma spp. from coconut palms affected by lethal yellowing disease in Jamaica. Curr. Microbiol. 2:311-316.

13. Gilliland, G., Perrin, S., Blanchard, K., and Bunn, H. F. 1990. Analysis of cytokine mRNA and DNA: Detection and quantitation by competitive polymerase chain reaction. Proc. Natl. Acad. Sci. U.S.A. 87:2725-2729.

14. Goswami, B. B., Koch, W. H., and Cebula, T. A. 1994. Competitor template RNA for detection and quantitation of hepatitis A virus by PCR. BioTechniques 16:114-121.

15. Grünebach, F., Griese, E.-U., and Schumacher, K. 1994. Competitive nested polymerase chain reaction for quantification of human MDR1 gene expression. J. Cancer Res. Clin. Oncol. 120:539-544.

16. Hahn, M., Dörsam, V., Friedhoff, P., Fritz, A., and Pingoud, A. 1995. Quantitative polymerase chain reaction with enzyme-linked immunosorbent assay detection of selectively digested amplified sample and control DNA. Anal. Biochem. 229:236-248.

17. Herrmann, R. 1992. Genome structure and organization. Pages 157-168 in: Mycoplasmas. Molecular Biology and Pathogenesis. J. Maniloff, R. N. McElhaney, L. R. Finch, and J. B. Baseman, eds. American Society for Microbiology, Washington, DC.

18. Hu, X., Lai, F.-M., Reddy, A. S. N., and Ishimaru, C. A. 1995. Quantitative detection of Clavibacter michiganensis subsp. sepedonicus by competitive polymerase chain reaction. Phytopathology 85:1468-1473.

19. Kartte, S., and Seemüller, E. 1991. Histopathology of apple proliferation in Malus taxa and hybrids of different susceptibility. J. Phytopathol. 131: 149-160.

20. Kartte, S., and Seemüller, E. 1991. Susceptibility of grafted Malus taxa and hybrids to apple proliferation disease. J. Phytopathol. 131:137-148.

21. Lederer, W., and Seemüller, E. 1991. Occurrence of mycoplasma-like organisms in diseased and non-symptomatic alder trees (Alnus spp.). Eur. J. For. Pathol. 21:90-96.

22. Lee, I.-M., Bertaccini, A., Vibio, M., and Gundersen, D. E. 1995. Detection of multiple phytoplasmas in perennial fruit trees with decline symptoms in Italy. Phytopathology 85:728-735.

23. Liu, H. W., Goodwin, P. H., and Kuske, C. R. 1994. Quantification of DNA from aster yellows mycoplasmalike organism in aster leafhoppers (Macrosteles fascifrons Stål) by competitive polymerase chain reaction. 
Syst. Appl. Microbiol. 17:274-280.

24. Lorenz, K.-H., Schneider, B., Ahrens, U., and Seemüller, E. 1995. Detection of the apple proliferation and pear decline phytoplasmas by PCR amplification of ribosomal and nonribosomal DNA. Phytopathology 85: 771-776.

25. Lüneberg, E., Jensen, J. S., and Frosch, M. 1993. Detection of Mycoplasma pneumoniae by polymerase chain reaction and nonradioactive hybridization in microtiter plates. J. Clin. Microbiol. 31:1088-1094.

26. Marchuk, D., Drumm, M., Saulino, A., and Collins, F. S. 1991. Construction of T-vectors, a rapid and general system for direct cloning of unmodified PCR products. Nucleic Acids Res. 19:1154.

27. Marcone, C., Ragozzino, A., and Seemüller, E. 1996. Association of phytoplasmas with the decline of European hazel in southern Italy. Plant Pathol. 45:857-863.

28. Marcone, C., Ragozzino, A., and Seemüller, E. 1996. Detection of an elm yellows-related phytoplasma in eucalyptus trees affected by littleleaf disease in Italy. Plant Dis. 80:669-673.

29. McCoy, R. E., Caudwell, A., Chang, C. J., Chen, T. A., Chiykowski, L. N., Cousin, M. T., Dale, J. L., de Leeuw, G. T. N., Golino, D. A., Hackett, K. J., Kirkpatrick, B. C., Marwitz, R., Petzold, H., Sinha, R. C., Sugiura, M., Whitcomb, R. F., Yang, I. L., Zhu, B. M., and Seemüller, E. 1989. Plant diseases associated with mycoplasma-like organisms. Pages 545640 in: The Mycoplasmas, Vol. V. R. F. Whitcomb and J. G. Tully, eds. Academic Press, San Diego, CA.

30. Mutasa, E. S., Chwarszczynska, D. M., and Asher, M. J. C. 1996. Singletube, nested PCR for the diagnosis of Polymyxa betae infection in sugar beet roots and colorimetric analysis of amplified products. Phytopathology 86:493-497.

31. Piatak, M., Luk, K.-C., Williams, B., and Lifson, J. D. 1993. Quantitative competitive polymerase chain reaction for accurate quantitation of HIV DNA and RNA species. BioTechniques 14:70-80.

32. Piatak, M., Saag, M. S., Yang, L. C., Clark, S. J., Kappes, J. C., Luk, K.-C., Hahn, B. H., Shaw, G. M., and Lifson, J. D. 1993. High levels of HIV-1 in plasma during all stages of infection determined by competitive PCR. Science 259:1749-1754.

33. Poggi Pollini, C., Giunchedi, L., and Bissani, R. 1997. Immunoenzymatic detection of PCR products for the identification of phytoplasmas in plants. J. Phytopathol. 145:371-374.

34. Pressacco, L., and Firrao, G. 1999. A general competitive polymerase chain reaction assay for the quantitation of phytoplasmas. First Internet
Conference on Phytopathogenic Mollicutes. Sponsored by University of Udine. On-line publication no. 1999/pres0100.

35. Razin, S. 1978. The mycoplasmas. Microbiol. Rev. 42:414-470.

36. Razin, S. 1994. DNA probes and PCR in diagnosis of mycoplasma infection. Mol. Cell. Probes 8:497-511.

37. Razin, S., Yogev, D., and Naot, Y. 1998. Molecular biology and pathogenicity of mycoplasmas. Microbiol. Mol. Biol. Rev. 62:1094-1156.

38. Sambrook, J., Fritsch, E. F., and Maniatis, T. 1989. Molecular Cloning: A Laboratory Manual, 2nd ed. Cold Spring Harbor Laboratory Press, Cold Spring Harbor, NY.

39. Schneider, B., Ahrens, U., Kirkpatrick, B. C., and Seemüller, E. 1993. Classification of plant-pathogenic mycoplasma-like organisms using restriction-site analysis of PCR-amplified 16S rDNA. J. Gen. Microbiol. 139:519-527.

40. Schneider, B., Seemüller, E., Smart, C. D., and Kirkpatrick, B. C. 1995. Phylogenetic classification of plant pathogenic mycoplasma-like organisms of phytoplasmas. Pages 369-380 in: Molecular and Diagnostic Procedures in Mycoplasmology, Vol. I. S. Razin and J. G. Tully, eds. Academic Press, San Diego, CA.

41. Seemüller, E., Kison, H., Lorenz, K.-H., Schneider, B., Marcone, C., Smart, C. D., and Kirkpatrick, B. C. 1998. Detection and identification of fruit tree phytoplasmas by PCR amplification of ribosomal and nonribosomal DNA. Pages 56-66 in: New Technologies to Improve Phytodiagnosis. C. Manceau and J. Spak, eds. Office of the Official Publications of the European Community, Luxembourg.

42. Seemüller, E., Marcone, C., Lauer, U., Ragozzino, A., and Göschl, M. 1998. Current status of molecular classification of the phytoplasmas. J. Plant Pathol. 80:3-26.

43. Sinha, R. C. 1983. Relative concentration of mycoplasma-like organisms in plants at various times after infection with aster yellows. Can. J. Plant Pathol. 5:7-10.

44. Smart, C. D., Schneider, B., Blomquist, C. L., Guerra, L. J., Harrison, N. A., Ahrens, U., Lorenz, K.-H., Seemüller, E., and Kirkpatrick, B. C. 1996. Phytoplasma-specific PCR primers based on sequences of the $16 \mathrm{~S}-23 \mathrm{~S}$ rRNA spacer region. Appl. Environ. Microbiol. 62:2988-2993.

45. Tjhie, J. H., van Kuppeveld, F. J., Roosendaal, R., Melchers, W. J., Gordijn, R., MacLaren, R., Walboomers, J. M., Meijer, C. J., and van den Brule, A. J. 1994. Direct PCR enables detection of Mycoplasma pneumoniae in patients with respiratory tract infections. J. Clin. Microbiol. 32:11-16. 